\title{
Food intake and serum levels of iron in children and adolescents with attention-deficit/hyperactivity disorder
}

\author{
Ingestão alimentar e níveis séricos de ferro em crianças e \\ adolescentes com transtorno de déficit de atenção/hiperatividade
}

\author{
Márcia Menegassi, ${ }^{1}$ Elza Daniel de Mello, ${ }^{2}$ Lísia Rejane Guimarães, ${ }^{3}$ Breno Córdova Matte, ${ }^{1}$ Fernanda Driemeier, \\ Gabriela Lima Pedroso, ${ }^{1}$ Luis Augusto Rohde, ${ }^{1}$ Marcelo Schmitz \\ 1 ADHD Outpatient Program, Child and Adolescent Psychiatric Division (PRODAH), Hospital de Clínicas de Porto Alegre (HCPA), \\ Porto Alegre, RS, Brazil \\ 2 Department of Nutrology, Hospital de Clínicas de Porto Alegre (HCPA), Porto Alegre, RS, Brazil \\ 3 Schizophrenia Program, Hospital de Clínicas de Porto Alegre (HCPA), Porto Alegre, RS, Brazil \\ ADHD Outpatient Program, Child and Adolescent Psychiatric Division, Hospital de Clínicas de Porto Alegre (HCPA), Porto Alegre, RS, Brazil
}

\begin{abstract}
Objective: To investigate hematologic variables related to iron deficiency and food intake in attention-deficit/hyperactivity disorder. Method: The sample comprised 62 children and adolescents (6-15 years old) divided into three groups: Group 1: 19 (30.6\%) patients with attentiondeficit/hyperactivity disorder using methylphenidate for 3 months; Group 2: 22 (35.5\%) patients with attention-deficit/hyperactivity disorder who were methylphenidate naïve and Group 3: 21 (33.9\%) patients without attention-deficit/hyperactivity disorder. Serum iron, ferritin, transferrin, hemoglobin, mean corpuscular volume, red cell distribution width, mean corpuscular hemoglobin concentration, nutritional diagnostic parameters - Body Mass Index Coefficient, food surveys were evaluated among the groups. Results: The attentiondeficit/hyperactivity disorder group drug naïve for methylphenidate presented the highest red cell distribution width among the three groups $(\mathrm{p}=0.03)$. For all other hematologic and food survey variables, no significant differences were found among the groups. No significant correlation between dimensional measures of attention-deficit/ hyperactivity disorder symptoms and ferritin levels was found in any of the three groups. Conclusion: Peripheral markers of iron status and food intake of iron do not seem to be modified in children with attentiondeficit/hyperactivity disorder, but further studies assessing brain iron levels are needed to fully understand the role of iron in attention-deficit/ hyperactivity disorder pathophysiology.
\end{abstract}

Descriptors: Nutritional status; Iron deficiency; Diet surveys; Attentiondeficit/hyperactivity disorder; Methylphenidate

\section{Resumo}

Objetivo: Investigar as variáveis hematológicas relacionadas à deficiência de ferro è à ingestão alimentar no transtorno de déficit de atenção/hiperatividade. Método: Sessenta e duas crianças e adolescentes (6-15 anos) divididos em três grupos: Grupo 1: 19 (30,6\%) pacientes com transtorno de déficit de atenção/hiperatividade com uso de metilfenidato durante três meses; Grupo 2: $22(35,5 \%)$ pacientes com transtorno de déficit de atenção/hiperatividade sem uso de medicamento; e Grupo 3: 21 (33,9\%) pacientes sem transtorno de déficit de atenção/hiperatividade. Ferro sérico, ferritina, transferrina, hemoglobina, volume corpuscular médio, amplitude de distribuição dos eritrócitos, concentração da hemoglobina corpuscular média, parâmetros de diagnóstico nutricional - Coeficiente de Indice de Massa Corporal, inquérito alimentar e a correlação entre os sintomas do transtorno e os niveis de ferritina foram avaliados. Resultados: O grupo com transtorno de déficit de atençãol hiperatividade não medicado com metilfenidato apresentou maior amplitude de distribuição dos eritrócitos dentre os três grupos $(p=0,03)$. Nas outras variáveis hematológicas e inquéritos alimentares näo encontramos diferença significativa entre os grupos. Não observamos correlação entre os sintomas do transtorno de déficit de atenção/hiperatividade e ferritina. Conclusão: Marcadores periféricos do estado nutricional de ferro e a ingestão alimentar de ferro não parecem estar modificados em crianças com transtorno de déficit de atenção/hiperatividade, mas mais estudos avaliando os niveis de ferro no cérebro são necessários para compreensão plena do papel do ferro na fisiopatologia do transtorno de déficit de atençāo/hiperatividade.

Descritores: Estado nutricional; Deficiência de ferro; Inquéritos alimentares; Transtorno de déficit de atenção/hiperatividade; Metilfenidato
Submitted: April 16, 2009

Accepted: July 20, 2009
Correspondence

Márcia Menegassi

PRODAH - HCPA

Rua Ramiro Barcellos, 2350

90035-003 Porto Alegre, RS, Brazil

Telefone/Fax: (+55 51) 3395-8094

E-mail: marciamenegassi@gmail.com 


\section{Introduction}

Several recent investigations on the neurobiology and treatment of Attention-Deficit/Hyperactivity Disorder (ADHD) have suggested that possible deficiencies of nutrients (i.e. iron, zinc, magnesium, polyunsaturated fatty acids) and sensitivity to some foods and food additives could be involved with the pathophysiology of the disorder. ${ }^{1-3}$

The iron is distributed heterogeneously in different regions and brain cells. The concentrations are not static, they increase with age and with some diseases, and decrease when the diet does not provide the required amount of nutrition. ${ }^{4}$

The brain iron homeostasis is required for its normal function; a decrease in iron concentration is accompanied by changes in the conduction of cortical fibers, changes in serotonergic and dopaminergic systems, as well as in the formation of myelin..$^{5-7}$

In children, there is an association between anemia caused by iron deficiency or iron deficiency without anemia and poor cognitive and motor development, and behavioral problems, ${ }^{4,8,9}$ indicating that iron plays an important role in normal functioning and neurological development. ${ }^{4}$ Significantly low levels of ferritin have been observed in children with ADHD, correlating with the severity of the symptoms. Since iron has a role as a cofactor of tyrosine hydroxylase, its decrease limits enzyme involvement in the synthesis of dopamine, and its deficiency may change the receptor density and the dopamine activity. ${ }^{10-12}$ The benefits of iron supplementation on attention function in children have been assessed through the use of neurophysiologic measures. The findings suggest that iron supplementation could improve attention in children with iron deficiency. ${ }^{13}$

However, other studies did not confirm the finding that iron deficiency plays a role in the pathophysiology of ADHD and, if so, whether oral administration of iron for affected children is recommended. ${ }^{14}$ Moreover, Millichap et al. found a proportion of children with ADHD with relatively low levels of ferritin suggestive of iron deficiency, but without a specific relationship to the symptoms and causes of ADHD. ${ }^{15}$

Due to the evidence of the involvement of iron in the dopamine metabolism, the relevance of dopaminergic systems in the pathopsysiology of ADHD and the controversial findings regarding the role of iron deficiency in ADHD etiology, our study sought to investigate levels of iron in the disorder, as well as undertake food surveys. Our hypothesis was that patients with $\mathrm{ADHD}$ show iron levels significantly lower than the control group and that this difference would be even greater in the group of patients with $\mathrm{ADHD}$ treated with $\mathrm{MPH}$, since findings in the literature suggest that low iron stores in children with $\mathrm{ADHD}$ who are taking medication ${ }^{15,16}$ might be due to a decreased appetite caused by these medications. ${ }^{17}$

\section{Method}

This was a controlled cross-sectional study. The sample was enrolled from the ADHD Outpatient Clinic at the Child and Adolescent Psychiatric Division of Hospital de Clínicas de Porto Alegre (PRODAH) from March 2006 to December 2008. The project was approved by the Ethical Committee of Hospital de
Clínicas de Porto Alegre, RS, Brazil (project number 05532). Written informed consent from parents or a legal guardian and assent from the child were obtained.

\section{Subjects}

Children and adolescents from the ADHD Outpatient Program were allocated into 2 groups: 1) group 1 - patients with ADHD, in exclusive and uninterrupted use of immediate-release $\mathrm{MPH}$ for 3 months; and 2) group 2 - patients with ADHD without medication use. A third group (control group) was also recruited from a primary care center linked with the University Hospital: 3) group 3 - control group, without ADHD or use of medication. For each patient diagnosed with $\mathrm{ADHD}$ (MPH naïve) a new patient with ADHD using MPH and a control subject were enrolled. All control patients were evaluated prior to the study by a pediatrician who ruled out the presence of infections and inflammatory processes and the use of drugs that could interfere in the serum iron levels.

Subjects were excluded if they had an IQ below 70, the coexistence of other psychiatric disorders with exception of Conduct Disorder (CD) and Oppositional Defiant Disorder (ODD), as well as any factor that could interfere in the serum iron level, including the use of supplemental iron in the past 3 months, parasitosis, acute or chronic infections, inflammatory processes, blood loss and chronic diarrhea. Illiterate patients were also excluded, due to the impossibility of completing the food survey.

\section{Diagnostic procedures}

The diagnostic process of ADHD and comorbid disorders for children and adolescents in our unit has been extensively described.${ }^{18}$ Briefly, the diagnosis of ADHD was obtained from the use of a semi-structured interview, Schedule for Affective Disorders and Schizophrenia for School-Age Children, Epidemiological Version (K-SADS-E) ${ }^{19}$ applied by trained research assistants and clinical evaluation of ADHD and comorbid conditions using DSM-IV ${ }^{20}$ criteria by child psychiatrists in interviews with the child and parents. For dimensional analyses of ADHD symptoms, we employed the Swanson, Nolan and Pelham - IV Questionnaire (SNAP-IV). ${ }^{21}$ Cognitive evaluation relied on the vocabulary and block design sub-tests of the Wechsler Intelligence Scale - Third Edition (WISC-III) 22 administered by a trained psychologist to estimate the children's overall IQ.

In addition, socioeconomic status (SES) was systematically collected from parents using the socioeconomic scale from Associação Brasileira de Institutos de Pesquisa de Mercado. ${ }^{23}$

\section{Laboratory measures}

For the parasitosis control, Parasitological Feces Exams were performed with three samples from each patient using the Hoffman, Pons and Janer method. ${ }^{24}$ The hematological exams were collected in the laboratory of the HCPA with minimum 4-hour fast for the serum iron assessment (Ferrozine colorimetric method), ferritin (electrochemiluminescence method), transferrin (immunoturbidimetry method) and 
hemoglobin, mean corpuscular volume (MCV), red cell distribution width (RDW), mean corpuscular hemoglobin concentration (MCHC) through absorbance of light/ impedance/flow cytometry method.

The following cut-off scores were used to indicate abnormal results: 1$)$ Hemoglobin: 5 to 11 years old $(<11.5 \mathrm{~g} / \mathrm{dl}), 12$ to 14 years old $(<12 \mathrm{~g} / \mathrm{dl})$, over 15 years old $(<13 \mathrm{~g} / \mathrm{dl}) ; 25$ ) Ferritin: 12 to $15 \mathrm{ng} / \mathrm{mL}^{26}$ and the cut-off used by Konofal et al. ${ }^{10,11}$ of $\leq 30 \mathrm{ng} /$ $\mathrm{mL}$ and by Cortese et al. ${ }^{12}$ of $\leq 45 \mathrm{ng} / \mathrm{mL}$; 3) RDW: $>14.5 \% ;^{26}$ 4) VCM: 5 to 8 years old ( 77 to $95 \mathrm{fL}$ ), 13 to 18 years old (78 to 96fL); ${ }^{12}$ 5) iron serum: $55-120 \mu \mathrm{g} / \mathrm{dL} ;{ }^{27}$ 6) $\mathrm{CHCM}$ : 31 to $37 \%{ }^{27}$ and 7) Transferrin: 170 to $250 \mathrm{mg} / \mathrm{dL}^{28}$

\section{Nutritional assessment}

After the selection of patients, a nutritional history and the measurement of weight and height were performed by a nutritionist. Three food surveys were applied to evaluate the dietary iron and caloric intake: 1) 24-Hour Dietary Recall; 2) Dietary record over 4 days (i.e. two weekdays and full weekend); 3) Food-Frequency Questionnaires.

The iron intake was measured from the amount of heme-iron found in high levels in red or dark meats. Heme-iron has an important nutritional benefit because the bioavailability of this form of dietary iron is high and generally it is not affected by important iron absorption inhibitors in the diet, such as polyphenols and phytate. $^{29}$

NutWin software ${ }^{30}$ was used to calculate the food surveys and Epi Info ${ }^{\mathrm{TM}}$ Version 3.5.1 (2008) to measure the nutritional indicator. The body mass index coefficient, BMI (weight in kilos divided by the square of height in meters) was used as the nutritional diagnosis parameter. Denoting the standard deviation as $\mathrm{SD}$, the following cut-offs (z-score) were used: 1) severe thinness if $\mathrm{BMI}<-3 \mathrm{SD}$; 2) thinness if $-3 \mathrm{SD}<\mathrm{BMI}<-2 \mathrm{SD}$; 3) eutrofic if $-2 \mathrm{SD}<\mathrm{BMI}<\mathrm{SD}$; 4) overweight if $\mathrm{SD}<\mathrm{BMI}<2 \mathrm{SD}$; and 5) obesity If BMI $>2 \mathrm{SD} .{ }^{31,32}$ At the end of this study, all participants received nutritional instructions comprised of a standard diet for their age, according to their food habits, and a food reeducation program was proposed to those who presented inadequate food intake.

\section{Statistical analysis}

The results were analyzed by Statistical Package for the Social Sciences Version 16.0 (SPSS). Continuous variables (age, schooling, IQ, hematologic variables, food surveys) were described through mean and standard deviation (symmetrical distribution) or median and interquartile range (asymmetrical distribution). Continuous data were presented as mean \pm standard deviation (SD) or median \pm interquartile range. Categorical data (gender, SES, ADHD subtypes, ODD, CD, cut-offs for iron deficient, nutritional assessment-BMI) were described as absolute and relative frequencies and p-values $<0.05$ were considered significant. For continuous variables, the differences among groups were assessed using One-Way Analysis of Variance (ANOVA) in case of a symmetrical distribution, or Kruskal-Wallis for asymmetrical distribution. Duncan test was applied to locate the statistical significance among groups. The Pearson's Chi-Square test was applied to compare the categorical variables among the groups. The relationship between SNAP and ferritin was assessed with Spearman's rho coefficient $\left(\mathrm{r}_{s}\right)$. The effect size assessment for clinical relevance was also calculated using the Effect Size Statistics (ES). ${ }^{33}$

\section{Results}

The sample was composed of 62 children and adolescents between 6 and 15 years old (average of 8.9 [sd $=2.5$ ] years), of which 46 (74.2\%) were male. The sample was divided into three groups: Group 1 - 19 (30.6\%), Group 2 - 22 (35.5\%) and Group $3-21$ (33.9\%). Table 1 shows the socio-demographic and clinical characteristics of the subjects.

A significant difference ( $\mathrm{p}=0.03$ ) among the groups was found only for RDW, with the highest detected levels in ADHD patients who were MPH naïve. However, we did not find significant differences among the groups $(\mathrm{p}=0.13)$ in the analyses based on the dichotomic RDW scores ( $\geq 14.5 \%$ ). In addition, only four patients had the RDW $\geq 14.5 \%$ associated with other hematological alterations $(\mathrm{MCV} \leq 77 \mathrm{fL}$ and/or ferritin $\leq 30 \mathrm{ng} /$

Table 1 - Socio-demographic and clinical characteristics

\begin{tabular}{|c|c|c|c|c|}
\hline Characteristics & Group 1 ( $n=19)$ & Group 2 (n = 22) & Group $3(n=21)$ & $\mathbf{p}$ \\
\hline Age (yrs) - (mean [sd]) & $8.8[2.4]$ & $9.0[2.6]$ & $8.9[2.7]$ & 0.99 \\
\hline Male $-\mathrm{n}(\%)$ & $15(78.9 \%)$ & $16(72.7 \%)$ & $15(71.4 \%)$ & 0.85 \\
\hline $\mathrm{IQ}-($ mean $[\mathrm{sd}])$ & $99.2[16.9]$ & $96.5[12.5]$ & $97.6 \pm 10.5$ & 0.81 \\
\hline ADHD subtypes - $n(\%)$ : & $13(68.4 \%)$ & $14(63.6 \%)$ & - & 0.3 \\
\hline \multicolumn{5}{|l|}{ Combined } \\
\hline Inattentive & & $3(15.8 \%)$ & $7(31.8 \%)$ & \\
\hline Hyperactive/Impulsive & & $3(15.8 \%)$ & $1(4.5 \%)$ & \\
\hline ODD-n (\%) & & $9(47.4 \%)$ & $12(54.5 \%)$ & $5(23.8 \%)$ \\
\hline CD-n (\%) & & $1(5.3 \%)$ & $1(4.5 \%)$ & 0 \\
\hline SES-n (\%): B - C & & $18(94.7 \%)$ & $22(100 \%)$ & $21(100 \%)$ \\
\hline $\begin{array}{l}\text { Schooling - (median } \pm \\
\text { iq/2) }\end{array}$ & & $1(0$ to 3$)$ & $1.5(0$ to 3.25$)$ & 2 (0 to 3.5$)$ \\
\hline
\end{tabular}

IQ: Intelligence quotient; ODD: Oppositional defiant disorder; $C D$ : Conduct disorder; SES: Socioeconomic status; ADHD: AttentionDeficit/Hyperactive Disorder. 
Table 2 - Hematological variables: mean (SD)

\begin{tabular}{lcccc}
\hline \multicolumn{1}{c}{ Characteristics } & Group 1 $(\mathbf{n}=\mathbf{1 9})$ & Group 2 $\mathbf{( n = 2 2 )}$ & Group 3 $(\mathbf{n}=\mathbf{2 1})$ & $\mathbf{p}$ \\
\hline Serum Iron & $80.6 \pm 30.3$ & $78.6 \pm 24.0$ & $92 \pm 31.4$ & 0.27 \\
Ferritin & $59.3 \pm 21.0$ & $54.2 \pm 17.2$ & $58.8 \pm 28.9$ & 0.72 \\
Transferrin & $270.9 \pm 25.9$ & $253.4 \pm 24.4$ & $267.1 \pm 29.3$ & 0.09 \\
Hemoglobin & $12.5 \pm 1.2$ & $12.6 \pm 0.9$ & $12.5 \pm 1.0$ & 0.93 \\
MCV & $81.0 \pm 6.4$ & $80.5 \pm 4.7$ & $83.7 \pm 5.2$ & 0.12 \\
MCHC & $32.9 \pm 0.9$ & $33.1 \pm 0.9$ & $32.9 \pm 0.9$ & 0.63 \\
RDW & $13.9 \pm 1.3^{*}$ & $14.7 \pm 1.1^{*}$ & $13.9 \pm 0.7^{*}$ & 0.03 \\
\hline
\end{tabular}

* in the line does not differ by Duncan Test; MCV: Mean corpuscular volume; RDW: Red cell distribution width; MCHC: Mean corpuscular hemoglobin concentration.

$\mathrm{mL}$ ). For the other hematologic variables evaluated in this study, there were no significant differences among the groups, as indicated in Table 2.

We also assessed all hematologic variables for iron deficiency or anaemia using designated cut-off scores (see Table 3). Anaemia was detected in all groups: $4(21.1 \%)$ patients in group 1, 2 (9.1\%) patients in group 2 and $3(14.3 \%)$ subjects in the control group. However, no significant differences were found among the groups $(\mathrm{p}=0.55)$. For ferritin, the minimum and maximum values observed were $15.5 \mathrm{ng} / \mathrm{mL}$ and $139.6 \mathrm{ng} / \mathrm{mL}$, and no significant difference was verified for the cut-off scores of $30 \mathrm{ng} / \mathrm{mL}(\mathrm{p}=$ $0.44)$ and $45 \mathrm{ng} / \mathrm{mL}(\mathrm{p}=0.96)$. Furthermore, no significant correlations were observed between the symptoms (measured by SNAP - inattentiveness, hyperactivity, ODD and total scores) and ferritin levels in all groups (see Table 4).

From these data, $8.1 \%$ of subjects had levels of ferritin $\leq 30 \mathrm{ng} /$ $\mathrm{mL}$, with more than half $(60 \%)$ from the control group. Values of $\leq 45 \mathrm{ng} / \mathrm{mL}$ were found in $24.2 \%$ of the sample, equally distributed in 5 patients of each group. No patient presented ferritin values $\leq 15 \mathrm{ng} / \mathrm{mL}$ and transferrin values of $\leq 170 \mathrm{mg} / \mathrm{dL}$.

Ten subjects $(16.1 \%)$ presented serum iron below $55 \mathrm{~g} / \mathrm{dL}$, $5(8.1 \%)<$ VCM $77 \mathrm{fL}$ and $2(3.2 \%)$ had values of $\mathrm{MCHC}<$ $31 \%$, and again no significant difference $(\mathrm{p}=0.53, \mathrm{p}=0.08$ and $\mathrm{p}=0.56$, respectively) was verified among the groups.

The values of heme-iron from food surveys (Table 5) were not significantly different among the groups in the 24-hour recall $(p=0.62)$, dietary record $(p=0.62)$ and food-frequency questionnaire $(\mathrm{p}=0.81)$.
The food intake (Table 5) measured by total intake of calories also showed no significant difference among the groups, both for intake measured using the 24-hour recall $(\mathrm{p}=0.54)$ and dietary record $(\mathrm{p}=0.39)$.

In all groups, a predominance of the eutrophic nutritional status according to BMI was observed: 14 (73.7\%) subjects in the MPH use group, 17 (77.3\%) individuals in the group with ADHD who were MPH naïve and 16 (76.2\%) subjects in the control group (Figure 1). No significant difference was found among the groups ( $\mathrm{p}=0.88)$. Only one patient $(5.3 \%)$ in group 1 had thinness according to BMI (z-score $<-2)$.

\section{Discussion}

To our knowledge, this is the first report investigating the association between serum levels of iron and ADHD, controlling for several potential confounders and including the use of methylphenidate. In addition, we are not aware of other studies comparing food surveys of patients with ADHD to controls. Our results suggest a lack of significant difference in the hematologic variables and food intake among patients with ADHD using medication, ADHD not medicated and non-ADHD patients.

Although a significant difference in RDW was found, the literature indicates that the RDW for the diagnosis of iron deficiency should be considered with MCV and ferritin. ${ }^{34-36}$ Due to the performance limitation of each isolated biochemical test, the literature suggests that joint analyses should be used to increase the sensitivity and specificity to the diagnosis of iron deficiency. ${ }^{35,37}$ In our study, only four subjects had other hematologic changes

Table 3 - Laboratory measures and cut-off scores for iron deficiency (\%)

\begin{tabular}{lcccc}
\hline \multicolumn{1}{c}{ Characteristics } & Group 1 (n = 19) & Group 2 (n = 22) & Group 3 (n = 21) & p \\
\hline Anemia (Hemoglobin g/dL) & $4(21.1 \%)$ & $2(9.1 \%)$ & $3(14.3 \%)$ & 0.56 \\
Ferritin $\leq 15 \mathrm{ng} / \mathrm{mL}$ & 0 & 0 & 0 & - \\
Ferritin $\leq 30 \mathrm{ng} / \mathrm{mL}$ & $1(5.3 \%)$ & $1(4.5 \%)$ & $3(14.3 \%)$ & 0.44 \\
Ferritin $\leq 45 \mathrm{ng} / \mathrm{mL}$ & $5(26.3 \%)$ & $5(22.7 \%)$ & $5(23.8 \%)$ & 0.96 \\
Serum Iron $\leq 55 \mathrm{\mu g} / \mathrm{dL}$ & $4(21.1 \%)$ & $2(9.1 \%)$ & $4(19 \%)$ & 0.53 \\
Transferrin $\leq 170 \mathrm{mg} / \mathrm{dL}$ & 0 & 0 & 0 & - \\
MCV $\leq 77 \mathrm{fL}$ & $1(5.3 \%)$ & $4(18.2 \%)$ & 0 & 0.08 \\
MCHC $\leq 31 \%$ & $1(5.3 \%)$ & 0 & $1(4.8 \%)$ & 0.56 \\
RDW $\geq 14.5 \%$ & $6(31.6 \%)$ & $13(59.1 \%)$ & $7(33.3 \%)$ & 0.13 \\
\hline
\end{tabular}

MCV: Mean corpuscular volume; RDW: Red cell distribution width; MCHC: Mean corpuscular hemoglobin concentration. 


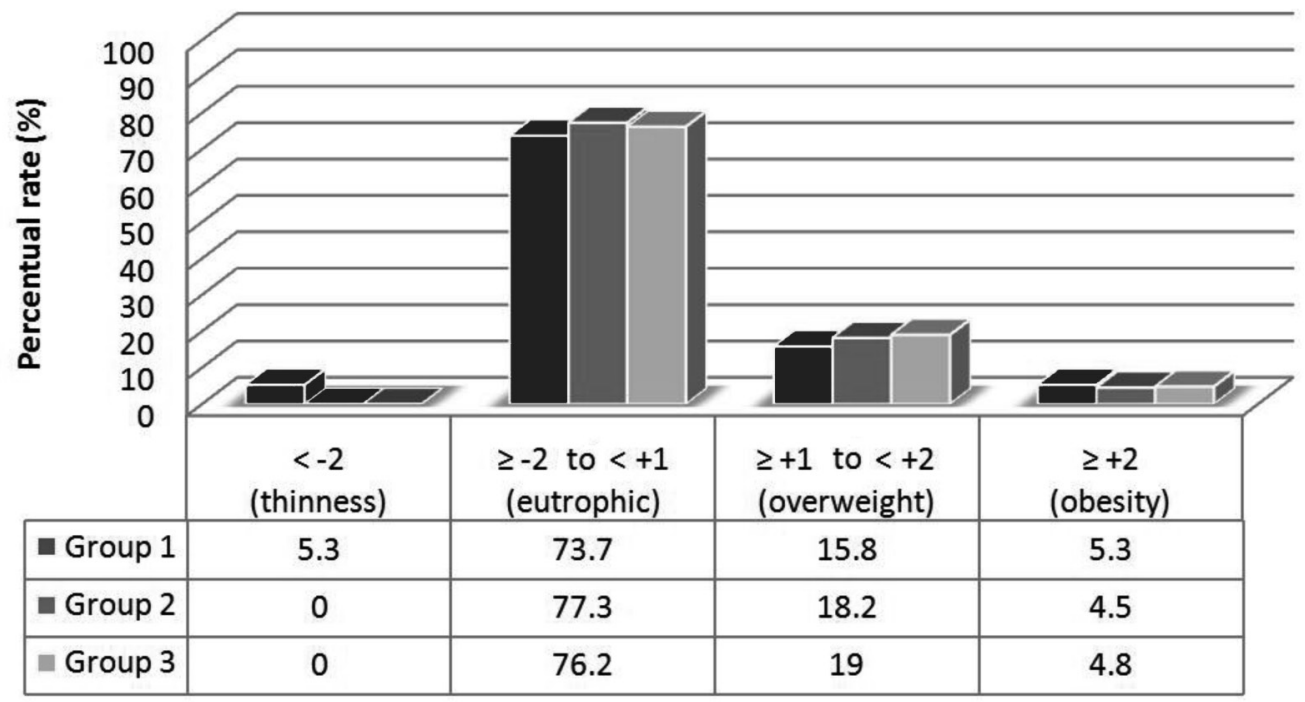

Figure 1 - Nutritional Assessment (\%): Body Mass Index (BMI) z-score; $p=0.88$

associated with abnormal RDW values, which would be suggestive of iron deficiency.

Some reports suggested that iron (usually assessed by ferritin levels) is closely associated with the severity of ADHD and comorbid symptoms. ${ }^{10-12}$ However, no correlations between ADHD symptoms and ferritin levels were observed in any groups of our study. Moreover, the frequency of iron deficiency was considerably higher in the studies performed by Konofal et al. ${ }^{10,11}$ that used a cut-off score for the ferritin $\leq 30 \mathrm{ng} /$ $\mathrm{dL}$ (> $80 \%$ of their ADHD sample had iron deficiency) and in the study of Cortese et al., ${ }^{12}$ where $60 \%$ of the patients presented serum ferritin levels $\leq 45 \mathrm{ng} / \mathrm{dL}$. However, our results demonstrated lower prevalence of ferritin values $\leq 30 \mathrm{ng} / \mathrm{dL}$ and $\leq 45 \mathrm{ng} / \mathrm{dL}$ ( $8.1 \%$ and $24.2 \%$, respectively). These results raise some doubts about whether iron deficiency might have physiological significance in ADHD and if the ferritin levels used as reference in other studies could be falsely altered due to acute or chronic inflammation or the presence of infection. ${ }^{38}$

To assess food behavior with higher precision, we quantified the food intake by associating different types of surveys, since no method is available for the food consumption assessment that is free of drawbacks and biases. ${ }^{39}$ Moore et al. showed that the items associated with an unhealthy diet may be omitted from the questionnaires, and factors such as lower socio-economic
Table 4 - Correlation $\left(r_{s}\right)$ between ADHD symptoms and ferritin levels $(p<0.05)$

\begin{tabular}{lccc}
\hline \multicolumn{1}{c}{ SNAP } & $\begin{array}{c}\text { Group 1 } \\
(\mathbf{n}=\mathbf{1 9})\end{array}$ & $\begin{array}{c}\text { Group 2 } \\
(\mathbf{n}=\mathbf{2 2})\end{array}$ & $\begin{array}{c}\text { Group 3 } \\
(\mathbf{n}=\mathbf{2 1})\end{array}$ \\
\hline Total & -0.05 & -0.08 & 0.19 \\
Inattentive & $\mathrm{p}=0.83$ & $\mathrm{p}=0.72$ & $\mathrm{p}=0.41$ \\
& 0.08 & -0.06 & 0.24 \\
Hyperactivity & $\mathrm{p}=0.74$ & $\mathrm{p}=0.80$ & $\mathrm{p}=0.32$ \\
& 0.06 & -0.32 & 0.12 \\
Oppositional & $\mathrm{p}=0.79$ & $\mathrm{p}=0.15$ & $\mathrm{p}=0.63$ \\
& 0.13 & 0.03 & 0.23 \\
& $\mathrm{p}=0.60$ & $\mathrm{p}=0.90$ & $\mathrm{p}=0.32$ \\
\hline
\end{tabular}

$r_{s}=$ Spearman-rank correlation coefficient

class and school performance may be associated with bias in reporting food consumption. ${ }^{40}$

According to D'Amato, ${ }^{16}$ low iron stores in children with ADHD who are taking medication. as reported in the literature, ${ }^{10}$ might be due to decreased appetite associated with these medications and additionally that those with ADHD (whether they are taking medications or not) might have reduced ability to sit still for a meal and therefore decreased nutritional intake of iron. ${ }^{16}$ However, we did not observe suppression of appetite caused by medication, or any effect on feeding behavior caused by the mechanisms intrinsic

Table 5 - Food surveys

\begin{tabular}{lcccc}
\hline \multicolumn{1}{c}{ Characteristics } & Group 1 $(\mathbf{n}=\mathbf{1 9})$ & Group 2 $(\mathbf{n}=\mathbf{2 2})$ & Group 3 $(\mathbf{n}=\mathbf{2 1})$ & $\mathbf{p}$ \\
\hline $\begin{array}{l}\text { 24-hour dietary recall-kcal } \\
\text { (mean } \pm \text { sd) }\end{array}$ & $2.025 \pm 1.012$ & $1.836 \pm 691$ & $2.113 \pm 809$ & 0.55 \\
Record dietary-kcal (mean \pm & $2.021 \pm 815$ & $1.942 \pm 544$ & $2.147 \pm 591$ & 0.60 \\
sd) & $1.5(1.1-5.7)$ & $2.6(1.1-3.8)$ & $2.4(1.6-6.7)$ & 0.62 \\
Heme iron* (median $\pm \mathrm{iq} / 2)$ & $3.5(2-5.1)$ & $2.8(2.5-5.1)$ & $4.3(3.1-5.3)$ & 0.62 \\
Heme iron ${ }^{* *}$ (median $\left.\pm \mathrm{iq} / 2\right)$ & $3.0(1.4-4.8)$ & $3.0(2.1-4.6)$ & $3.6(2.1-5.2)$ & 0.81 \\
Heme iron $^{* *}$ (median $\left.\pm \mathrm{iq} / 2\right)$ & & & & \\
\hline
\end{tabular}

* Obtained with the 24-hour Dietary Recall; ** Obtained with the Dietary Record for 4 days; *** Obtained with Food - Frequency Questionnaires. 
to ADHD in the food intake of heme-iron and energy among the groups of $\mathrm{ADHD}$ children medicated, not medicated or the control group.

The attention to the length of time on stimulants or on other medications, as well as the withdrawal of medication 2 to 3 months before the study, were mentioned in some investigations, ${ }^{11,15,35}$ but it is not clear either whether this prior period of medication suspension would be sufficient to normalize possible nutritional deficiencies, or which drugs were used and for how long they were used before the interruption in most studies. These factors might justify the deficiencies of iron reported by these authors.

Although the most adverse effects of medications are mild and transient, there is a concern about the effect of these drugs on weight and growth. ${ }^{17}$ In our study, patients using methylphenidate exclusively and continuously for three months showed no differences in the nutritional food intake compared to the group without medication and the control group. Furthermore, no difference was observed in the anthropometric measurements among the groups.

Our findings should be considered in the light of the following limitations. First, the three-month period of medication use might not have been sufficient to change the hematological variables or the patient's growth. Also, we might not have been able to detect significant differences in most variables because of our limited sample size. However, taking the ferritin variable as an example, establishing the means and SD of the groups as found and accepting a study power of $90 \%$, we would need at least 225 in each group to detect a difference at a 5\% significance level. Moreover, effect sizes found were small among the groups (medicated ADHD vs. drug naive ADHD, ES: 0.27; medicated ADHD vs. control, ES: 0.02; drug naive ADHD vs. control, ES: 0.19), documenting that between-group differences were of low clinical relevance. In addition, our sample size was similar to that of other studies on this subject in the literature. ${ }^{10,12,15,36}$

\section{Conclusion}

We believe that the results of our study contribute to the understanding of the role of iron in the disorder, adding to the findings in the literature and suggesting that peripheral iron levels and food intake of iron did not differ between patients with ADHD and controls. Therefore, we suggest that future studies evaluating the levels of iron in the brain should be performed to confirm whether this mineral is involved in the pathophysiology of ADHD.

\section{Acknowledgements}

This study was supported by grants from Fundo de Incentivo à Pesquisa do Hospital de Clinicas de Porto Alegre (FIPE-HCPA) Project 05532.

\section{Disclosures}

\begin{tabular}{|c|c|c|c|c|c|c|c|}
\hline $\begin{array}{l}\text { Writing group } \\
\text { member }\end{array}$ & Employment & $\begin{array}{l}\text { Research } \\
\text { grant }^{1}\end{array}$ & $\begin{array}{c}\text { Other research grant } \\
\text { or medical continuous } \\
\text { education }^{2}\end{array}$ & $\begin{array}{l}\text { Speaker's } \\
\text { honoraria }\end{array}$ & $\begin{array}{l}\text { Ownership } \\
\text { interest }\end{array}$ & $\begin{array}{c}\text { Consultant/ } \\
\text { Advisory } \\
\text { board }\end{array}$ & Other $^{3}$ \\
\hline $\begin{array}{l}\text { Márcia } \\
\text { Menegassi }\end{array}$ & UFRGS* & $\begin{array}{c}\text { FIPE- } \\
\text { HCPA }^{* * *}\end{array}$ & - & - & - & - & - \\
\hline $\begin{array}{l}\text { Elza Daniel } \\
\text { de Mello }\end{array}$ & UFRGS** & $\begin{array}{l}\text { FIPE- } \\
\text { HCPA }^{* * *}\end{array}$ & - & Abbott* & - & - & $\begin{array}{c}\text { Artes } \\
\text { Médicas* }\end{array}$ \\
\hline $\begin{array}{l}\text { Lísia Rejane } \\
\text { Guimarães }\end{array}$ & UFRGS* & - & - & - & - & - & - \\
\hline $\begin{array}{l}\text { Breno Córdova } \\
\text { Matte }\end{array}$ & UFRGS* & - & - & - & - & - & - \\
\hline $\begin{array}{l}\text { Fernanda } \\
\text { Driemeier }\end{array}$ & UFRGS* & - & - & - & - & - & - \\
\hline $\begin{array}{l}\text { Gabriela Lima } \\
\text { Pedroso }\end{array}$ & UFRGS* & $\begin{array}{l}\text { PBIC- } \\
\text { UFRGS* }\end{array}$ & - & - & - & - & - \\
\hline $\begin{array}{l}\text { Luis Augusto } \\
\text { Rohde }\end{array}$ & UFRGS** & $\begin{array}{l}\text { FIPE- } \\
\text { HCPA }^{* * *}\end{array}$ & $\begin{array}{l}\text { Novartis } \\
\text { Eli-Lilly***} \\
\text { Janssen-Cilag*** } \\
\text { Abbott***} \\
\text { Shire } \\
\text { Sh** }\end{array}$ & $\begin{array}{l}\text { Novartis* } \\
\text { Eli-Lilly* } \\
\text { Janssen- } \\
\text { Cilag* }\end{array}$ & - & $\begin{array}{l}\text { Novartis* } \\
\text { Eli-Lilly* } \\
\text { Janssen- } \\
\text { Cilag* }\end{array}$ & $\begin{array}{l}\text { Novartis* } \\
\text { Artes } \\
\text { Médicas* }\end{array}$ \\
\hline $\begin{array}{l}\text { Marcelo } \\
\text { Schmitz }\end{array}$ & UFRGS** & $\begin{array}{l}\text { FIPE- } \\
\text { HCPA }^{* * *} \\
\mathrm{CNPq}^{* *}\end{array}$ & $\begin{array}{c}\text { Shire }{ }^{* *} \\
\text { Novartis }^{* *}\end{array}$ & $\begin{array}{l}\text { Novartis** } \\
\text { Janssen**}\end{array}$ & - & - & - \\
\hline \multicolumn{8}{|c|}{$\begin{array}{l}\text { *Modest } \\
{ }^{* *} \text { Significant } \\
\text { *** Significant. Amounts given to the author's institution or to a colleague for research in which the author has participation, not directly to the author. } \\
\text { Note: UFRGS = Universidade Federal do Rio Grande do Sul; FIPE/HCPA = Fundo de Incentivo à Pesquisa do Hospital de Clínicas de Porto Alegre, } \\
\text { CNPq= Conselho Nacional de Desenvolvimento Cientifico e Tecnológico; PBIC-UFRGS = Programa de Bolsas de Iniciação Científica. } \\
\text { For more information, see Instructions for authors. }\end{array}$} \\
\hline
\end{tabular}




\section{References}

1. Rucklidge J, Johnstone J, Kaplan B. Nutrient supplementation approaches in the treatment of ADHD. Expert Rev Neurother. 2009;9(4):461-76.

2. Pelsser LM, Frankena K, Toorman J, Savelkoul HF, Pereira RR, Buitelaar JK. A randomised controlled trial into the effects of food on ADHD. Eur Child Adolesc Psychiatry. 2008;18(1):12-9.

3. Sinn N. Nutrition and dietary influences on attention deficit hyperactivity disorder. Nutr Rev. 2008;66(10):558-68.

4. Lozoff B, Beard J, Connor J, Barbara F, Georgieff M, Schallert T. Longlasting neural and behavioral effects of iron deficiency in infancy. Nutrition Rev. 2006;64(5 Pt 2):S34-S43; discussion S72-91.

5. Ben-Schachar D, Levine E, Spanier I, Zur R, Youdim MD. Iron modulates neuroleptic-induced effects related to the dopaminergic system. Isr J Med Sci. 1993;29(9):587-92.

6. Erikson KM, Jones BC, Hess EJ, Zhang Q, Beard JL. Iron deficiency decreases dopamine D1 and D2 receptors in rat brain. Pharmacol Biochem Behav. 2001;69(3-4):409-18

7. Beard J. Iron deficiency alters brains development and functioning. J Nutr. 2003;133(5 Suppl 1):1468S-72S.

8. Aggett PJ. Iron metabolism and requirements in early childhood: do we Know enough?: a hyperactive by ESPGHAN committee on nutrition. J Pediatr Gastroenterol Nutr. 2002;34(4):337-45.

9. Halterman JS, Kaczorowski JM, Aligne CA, Auinger P, Szilagyi PG. Iron deficiency and cognitive achievement among school-aged children and adolescents in the United States. Pediatrics. 2001;107(6):1381-6.

10. Konofal E, Lecendreux M, Arnulf I, Mouren MC. Iron deficient in children with attention-deficit/hyperactivity disorder. Arch Pediatr Adolescec Med. 2004;158(12):1113-5.

11. Konofal E, Lecendreux M, Deron J, Marcchand M, Cortese S, Zaïm M, Mouren MC, Arnuff I. Effects of iron supplementation on attention deficit hyperactivity disorder in children. Pediatr Neurol. 2008;38(1):20-6.

12. Cortese S, Konofal E, Bernardina BD, Mouren MC, Lecendreux M. Sleep disturbances and serum ferritin levels in children with attention-deficit/ hyperactivity disorder. Eur Child Adolesc Psychiatry. 2009;18(7):393-9.

13. Otero GA, Pliego-Rivero FB, Contrebas G, Ricardo J, Fernández T. Iron supplementation brings up a lacking P300 in iron deficient children. Clin Neurophysiol. 2004;115(10):2259-66.

14. Sever Y, Ashkenazi A, Tyano S, Weizman A. Iron treatment in children with attention deficit hyperactivity disorder: a preliminary report. Neuropsychobiology. 1997;35(4):178-80.

15. Millichap JG, Yee MM, Davidson SI. Serum ferritin in children with attentiondeficit hyperactivity disorder. Pediatr Neurol. 2006;34(3):200-3.

16. D'Amato T. Is iron deficiency causative of attention-deficit/hyperactivity disorder? Arch Pediatr Adolescec Med. 2005;159(8):788.

17. Faraone SV, Biederman J, Morley CP, Spencer TJ. Effect of stimulants on height and weight: a review of the literature. J Am Acad Child Adolesc Psychiatry. 2008;47(9):994-1009.

18. Rohde LA. ADHD in Brazil: the DSM-IV criteria in a culturally different population. J Am Acad Child Adolesc Psychiatry. 2002;41(9):1131-3.

19. Orvaschel H. Psychiatric interviews suitable for use in research with children and adolescents. Psychopharmacol Bull. 1985;21(4):737-45.

20. American Psychiatric Association. Diagnostic and statistical manual of mental disorders. 4th ed. Washington, DC: American Psychiatric Association (APA); 1994

21. Swanson JM, Kraemer HC, Hinshaw SP, Arnold LE, Conners CK, Abikoff HB, Clevenger W, Davies M, Elliott GR, Greenhill LL, Hechtman L, Hoza B, Jensen PS, March JS, Newcorn JH, Owens EB, Pelham WE, Schiller E, Severe JB, Simpson S, Vitiello B, Wells K, Wigal T, Wu M. Clinical relevance of the primary findings of the MTA: success rates based on severity of ADHD and ODD symptoms at the end of treatment. $J$ Am Acad Child Adolesc Psychiatry. 2001;40(2):168-79.

22. Weschler DI. Examiner's manual: Weschler intelligence scale for children, 3th ed. New York: Psychological Corporation; 1991.

23. Galduróz JCF, Noto AR, Carlini EA. IV Levantamento sobre o uso de drogas entre estudantes de primeiro e segundo graus em dez capitais brasileiras. São Paulo: Centro Brasileiro de Informações sobre Drogas Psicotrópicas; 1997.

24. Hoffman WA, Pons JA, Janer JL. The sedimentation concentration method in Schistosomiasis mansoni. Puerto Rico. J Public Health. 1934;9:283-91.

25. World Health Organization - WHO. Iron deficiency anaemia: assessment, prevention and control. A guide for programme managers. Geneva: World Health Organization; 2001. 114p.
26. World Health Organization - WHO/Centers for Disease Control and Prevention Technical Consultation. Assessment of iron status of populations: including literature reviews. 2nd ed. Geneva: World Health Organization; 2004.

27. Taketomo C, Holding J, Kraus D. Pediatric dosage handbook. 11th ed. Hudson, OH: LexiComp; 2004.

28. Lopes F, Junior D. Tratado de pediatria - Sociedade Brasileira de Pediatria. Barueri (SP): Manole; 2007.

29. Shills M; Shike M, Ross A, Caballero B, Cousins R. Modern Nutrition in health and disease. $10^{\text {th }}$ ed. Baltimore (MD): Lippincott Williams \& Wilkins; 2006.

30. Software NutWin Programa de Apoio à Nutrição. São Paulo: Escola Paulista de Medicina, Universidade Federal de São Paulo (Unifesp).

31. World Health Organization. WHO child growth standarts: body mass index-forage. Methods and development. WHO (nonserial publication). Geneva, Switzerland: WHO; 2006.

32. de Onis M, Onyango AW, Borghi E, Siyam A, Nishida C, Siekmann J. Development of a WHO growth reference for school-aged children and adolescents. Bull World Health Org. 2007;85(9):660-7.

33. Hopkins W. A new view of statistics. [cited 2009 apr 8] .Available from:http:// www.spotsci.org/resource/stats 2000 .

34. Paiva AA, Rondó P, Guerra-Shinohara E. Parameters for assessment of iron status. Rev Saude Publica. 2000;34(4):421-6.

35. Sociedade Brasileira de Pediatria-SBP. Anemia carencial ferropriva. Departamento Científico de Nutrologia da Sociedade Brasileira de Pediatria: São Paulo; 2007. 4p.

36. Oner O, Alkar OY, Oner P. Relation of ferritin levels with symptom ratings and cognitive performance in children with attention deficit-hyperactivity disorder. Pediatr Int. 2008;50(1):40-4.

37. Paiva Ade A, Rondó PH, Silva SS, Latorre Mdo R. Comparison between the HemoCue and an automated counter for measuring hemoglobin. Rev Saude Publica. 2004;38(4):585-7.

38. Picchietti D. Is iron an underlying cause of pediatric restless legs syndrome and of attention-deficit/hyperactivity disorder? Slepp Med. 2007;8(7-8):693-4.

39. Falcão-Gomes R, Coelho A, Schmitz B. Characterization of dietary intake assessment studies in pré-school children. Rev Nutr. 2006;19(6):713-27.

40. Moore GF, Tapper K, Moore L, Murphy S. Cognitive, behavioral and social factors are associated with bias in dietary questionnaire self-reports by schoolchildren aged 9 to 11 years. J Am Diet Assoc. 2008;108(11): $1865-73$. 